\title{
PREVALENCE OF THE FACTOR V LEIDEN MUTATION IN PATIENTS SUSCEPTIBLE TO VENOUS THROMBOEMBOLISM
}

\section{CZĘSTOŚĆ WYSTĘPOWANIA MUTACJI CZYNNIKA V LEIDEN U PACJENTÓW ZE SKŁONNOŚCIĄ DO ŻYLNEJ CHOROBY ZAKRZEPOWO-ZATOROWEJ}

\author{
Joanna Małgorzata Mitrus ${ }^{1(\mathrm{C}, \mathrm{D}, \mathrm{E}, \mathrm{F}, \mathrm{G})}$, Elżbieta Wierszyło ${ }^{2(\mathrm{~A}, \mathrm{~B}, \mathrm{~F})}$ \\ ${ }^{1}$ University of Natural Sciences and Humanities in Siedlce, Poland \\ ${ }^{2}$ Central Laboratory of University Clinical Center in Gdańsk, Poland
}

Authors' contribution Wkład autorów:

A. Study design/planning zaplanowanie badań B. Data collection/entry zebranie danych C. Data analysis/statistics dane - analiza i statystyki D. Data interpretation interpretacja danych E. Preparation of manuscript przygotowanie artykułu F. Literature analysis/search wyszukiwanie i analiza literatury G. Funds collection zebranie funduszy
Tables: 1

Figures: 9

References: 40

Submitted: 2020 Feb 25

Accepted: 2020 March 31

\section{Summary}

Background. A tendency to venous thromboembolism is otherwise called hypercoagulability or thrombophilia. This disease can be acquired or have a genetic background, and may lead to pulmonary embolism. The basis for analysis and selection of treatment is genetic diagnosis, which detects the G1691A mutation in the factor V gene (factor V Leiden) - the best known congenital thrombophilia marker.

Material and methods. The study was carried out in the years 2015-2017 on samples taken from patients ( 462 men and 1284 women) with a tendency to venous thromboembolism. RealTime PCR was used to detect G1691A mutation in factor V gene. The analyses were performed in the Hematology Laboratory of the Center of Laboratory Medicine at the Medical University of Gdańsk.

Results. Significant differences in the frequency of Leiden mutation were shown. This mutation predominated in men (25\%), while in women G1691A mutation was detected with a $15 \%$ frequency $(p=0.04)$. All possible genotypes were found among the subjects and the percentage of heterozygotes and homozygotes in both genders was similar.

Conclusions. Congenital thrombophilia associated with G1691A mutation of factor V Leiden gene was found to be more common in men than in women. All possible genotypes were determined in the pool of test subjects. The mutation was most frequently detected in patients between 30 and 40 years of age, and rarely after 70 years of age.

Keywords: hypercoagulability, Leiden mutation, genotyping techniques, Real-Time PCR

\section{Streszczenie}

Wprowadzenie. Nadkrzepliwość (trombofilia) jest to skłonność do żylnej choroby zakrzepowozatorowej. Choroba ta może być nabyta lub mieć podłoże genetyczne i może prowadzić do zatorowości płucnej. Podstawą analizy i doboru leczenia jest diagnostyka genetyczna. Celem tej diagnostyki jest wykrycie mutacji G1691A w genie czynnika V (czynnik V Leiden) - najlepiej poznanego markera trombofilii wrodzonej.

Materiałimetody. Badaniazostały przeprowadzonewlatach 2015-2017 na próbkach pobranych od pacjentów (462 mężczyzn i 1284 kobiet) ze skłonnością do żylnej choroby zakrzepowozatorowej. W celu wykrycia mutacji G1691A w genie czynnika V zastosowano metodę RealTime PCR. Analizy zostały wykonane w Laboratorium Hematologii Uniwersyteckiego Centrum Medycyny Laboratoryjnej przy Gdańskim Uniwersytecie Medycznym.

Wyniki. Wykazano istotne statystycznie różnice w częstości występowania mutacji Leiden. Mutację częściej występowała w grupie mężczyzn (25\%), zaś u kobiet mutację G1691A wykrywano z częstością 15\% ( $\mathrm{p}=0,04)$. Wśród osób badanych stwierdzono wszystkie możliwe genotypy, a procentowy udział heterozygot i homozygot u obu płci był zbliżony.

Wnioski. Trombofilia wrodzona związana z mutacją G1691A w genie czynnika V Leiden częściej występowała u mężczyzn niż kobiet. W puli osób poddanych testom oznaczono wszystkie możliwe genotypy. Mutację najczęściej wykrywano u pacjentów w przedziale wiekowym 3040 lat, a najrzadziej po 70 roku życia.

Słowa kluczowe: nadkrzepliwość, mutacja Leiden, genotypowanie, Real-Time PCR 


\section{Introduction}

Thrombophilia (hypercoagulability) is an acquired or inborn tendency to form venal and, less frequently, arterial blood clots, which are caused by abnormal blood clotting. Acquired hypercoagulability is more frequent than the genetic one and may be caused by various factors, e.g. cancer, drugs (contraception), specific medical condition of the patient (e.g. childbirth, puerperium, surgery) but also antiphospholipid syndrome (APS) [1, 2]. Thromboembolism (VTE) often complicated with pulmonary artery embolism are the main symptoms of thrombophilia. It is a disease of multifactorial aetiology and may be caused by environmental and genetic factors. Clinically, it manifests itself in the form of thrombosis (embolism) in the deep vein system, mainly in the lower limbs. This is less common ( $5 \%$ of all thromboembolism cases) in abdominal veins, cerebral venous sinuses, upper limb venous vessels, middle retinal vein or hepatic vessels [2-6].

Due to the formation of clots in blood vessels and their ability to circulate to different organs, hypercoagulation may be life-threatening condition. It is most often associated with stroke, myocardial infarction, and can also lead to early miscarriages. The rupture of the thrombus may result in pulmonary embolism [4, 6]. It is a diagnostic challenge, especially in cases where the clinical signs are barely visible or are masked by other conditions. Often in members of the same family the clinical course of thrombophilia may be different even if it is caused by the same genetic defect. Regardless of whether the underlying causes of the thrombosis are acquired or genetic, the risk of lifelong blood clotting is increased [2, 6, 7].

Although the progress in venous thromboembolism prophylaxis seems significant, it still affects $1 / 1000$ people in the industrialized countries every year, $1-2 \%$ of whom die of pulmonary embolism. In Poland there are about 50-80 thousand new cases per year whereas in the USA - 300-600 thousand new cases. Data provided by the National Consultant in the field of general surgery (Prof. Jan Kulig 2008) indicate that the incidence of thrombosis is most prevalent in people over 40 years of age, more often in men (average age 45 years), which is: 0.25 cases/1000/year under 40 years of age, 3 cases/1000/year under 85-89 years of age. Also epidemiological data from the year 2015 indicate that the incidence of this disease increases with age. In the risk group there are patients aged 40 years and over and $70 \%$ of them are people over 60 years old [8,9]. Nowadays, alongside heart disease and cancer, it is the most common cause of death. It occurs in about $10 \%$ of the general population of the Caucasian race and constitutes $30-50 \%$ of cases of venous thromboembolism $[6,10,11]$. This disease is also associated with the risk of chronic pulmonary hypertension and post-thrombotic syndrome, in addition to being a direct life-threatening condition, which is a consequence of an inadequate or belated diagnosis of thrombotic disease. It is a public health problem affecting the quality of life [12]. Therefore, it is essential to diagnose people prone to thrombosis as early as possible, especially those genetically predisposed towards it.

The aim of the study was to estimate the prevalence of Leiden point mutation in the population of patients referred for molecular tests.

\section{Material and methods}

\section{Characteristics of the test group}

The study was conducted in the years 2015-2017. Clinical material from 1746 patients (462 men and 1284 women), referred for molecular diagnostics towards Leiden mutation, was used. The analytic work was performed in the Hematology Laboratory of the Center of Laboratory Medicine (UMCL) at the Medical University of Gdańsk (UCK). Mean age of patients was 37 years, the youngest were newborns and the oldest patient was 87 years old. Most patients in the study (35.4\%) were aged from 30 to 40 years. Patients aged 80 to 90 years accounted for the lowest percentage $(0.3 \%)$. The age distribution of the study group is not consistent with normal distribution (Shapiro-Wilk W=0.98, p<0.001) (Figure 1). The average age of men was 38 years. The youngest was a newborn, and the oldest was 80 years old. Patients in the age range from 40 to 50 years were the most numerous group $(21.2 \%)$ and those in the age range from 70-80 years were the least numerous (3\%) (Figure 2). In the case of women, likewise men, the average age was 36 years. The youngest patient was a newborn, and the oldest one was 87 years old (Figure 3 ).

To verify the results obtained, the Shapiro-Wilk test (W) and the $\chi^{2}$ test with Statistica 12.0 (StatSoft) software were used. The authors have the consent of the Director of the University Clinical Center in Gdańsk to use the anonymized data. 


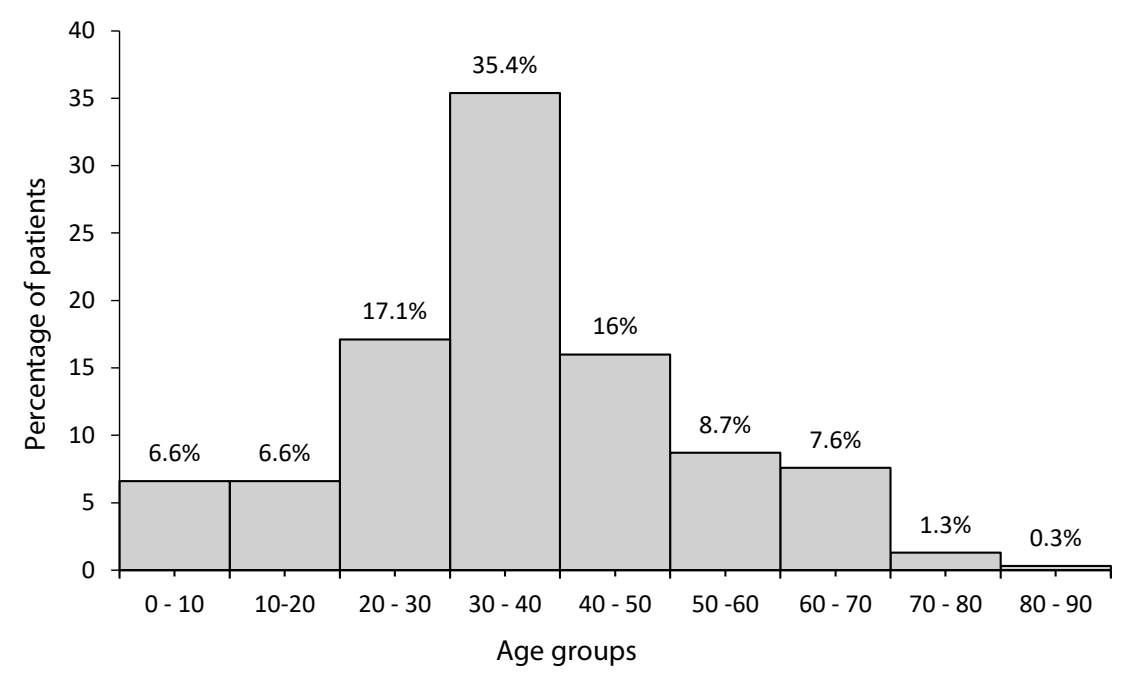

Figure 1. Age distribution of patients undergoing molecular diagnostics

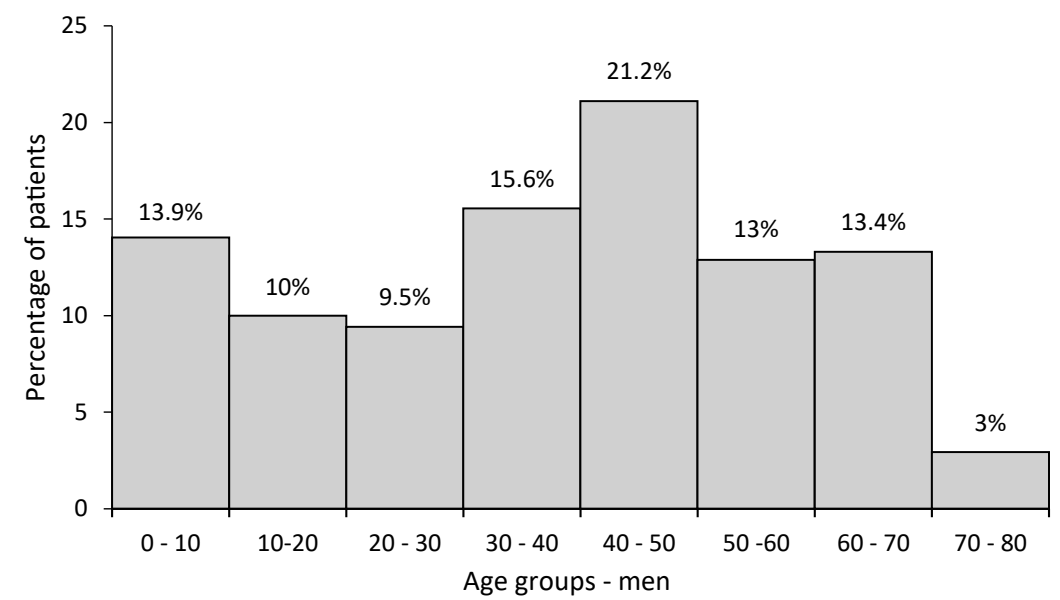

Figure 2. Age distribution of men undergoing molecular diagnostics

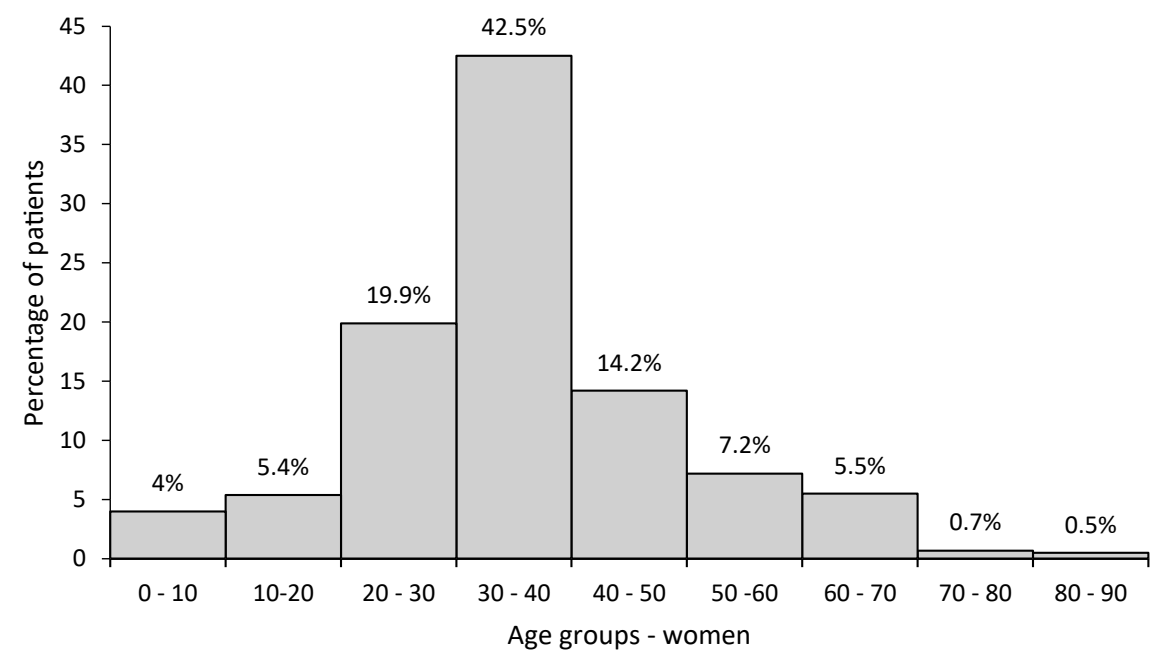

Figure 3. Age distribution of women undergoing molecular diagnostics

\section{Material collection and preparation for molecular testing}

The test material was peripheral blood collected in anticoagulants: EDTA-K3 or citrate. Each patient was sampled for min. $3 \mathrm{ml}$ of peripheral blood from which genomic DNA was isolated according to the procedure 
included in the High Pure PCR Template Preparation Kit (Roche). The DNA was amplified in a real-time polymerase chain reaction (Real-Time PCR). Each test sample was accompanied by a negative control without human DNA (buffer to prepare Master Mix (MMX) (FVL DIL) and a positive control (heterozygote, plasmid mixture: plasmid pCRF5 - wild type factor $\mathrm{V}$ gene, plasmid pCRF5MUT - mutated factor $\mathrm{V}$ gene). For the reaction, following reaction mixtures were used: $11 \mu \mathrm{l}$ - FVL DIL, $2 \mu \mathrm{l}$ - FVL MD Mix, $2 \mu \mathrm{l}$ - FVL R.

Using specific primers a DNA fragment of 222 base pairs was amplified. Amplicons were detected with HybProbe type probes. The probes contained two oligonucleotides complementary to internal amplicon sequences. Fluorophores were used to construct both labeled probes, the first marked at the $5^{\prime}$ end with LightCycler Red 640-NHS ester and the second marked at the 3' end with fluorescein. Fluorescence was detected after each cycle when both fragments were attached to the target sequence. Only then both fragments of the probe are close enough to allow a nonradiative energy transfer (FRET) from the excited fluorescein to the Red 640-NHS ester, which emits red light, measured by the LightCycler 2.0 detection system in the $640 \mathrm{~nm}$ channel.

\section{Genotyping}

After the PCR reaction, genotyping was performed automatically on the basis of the melting curve, i.e. the disappearance of fluorescence, when the temperature rises. The fluorescein probe was attached to a fragment of the gene which contained the tested genetic polymorphism. As a result of incomplete complementarity, the mutated sequence attachment to the probe was weaker than that of the wild sequence. The probe dissociates at a lower temperature from the mutated sequence than from the wild one, which was measured as a faster fluorescence fading. In order to accept the result, each graph was analyzed paying particular attention to melting temperature (Tm) values. The tested series were considered valid when the following results were obtained: 1 . for a negative control: Negative 2. for positive control (Control Template): het. If other results were obtained, the test was repeated.

\section{Possible genotypes}

There were three possible genotypes:

1. wild type genotype $(w t)$ - normal - no mutation detected,

2. heterozygote genotype (het) - one mutated allele,

3. homozygous "type" genotype - mutated genotype (mut) - two mutant alleles.

In the case of the wild genotype $(w t)$, one melting point $(\mathrm{Tm})$ of about $66^{\circ} \mathrm{C}$ was visible as a peak on the graph, which means that no mutation was detected. In the analyzed material the correct genotype was obtained in position 1691 of the coagulation factor V gene (G/G) (Figure 4).

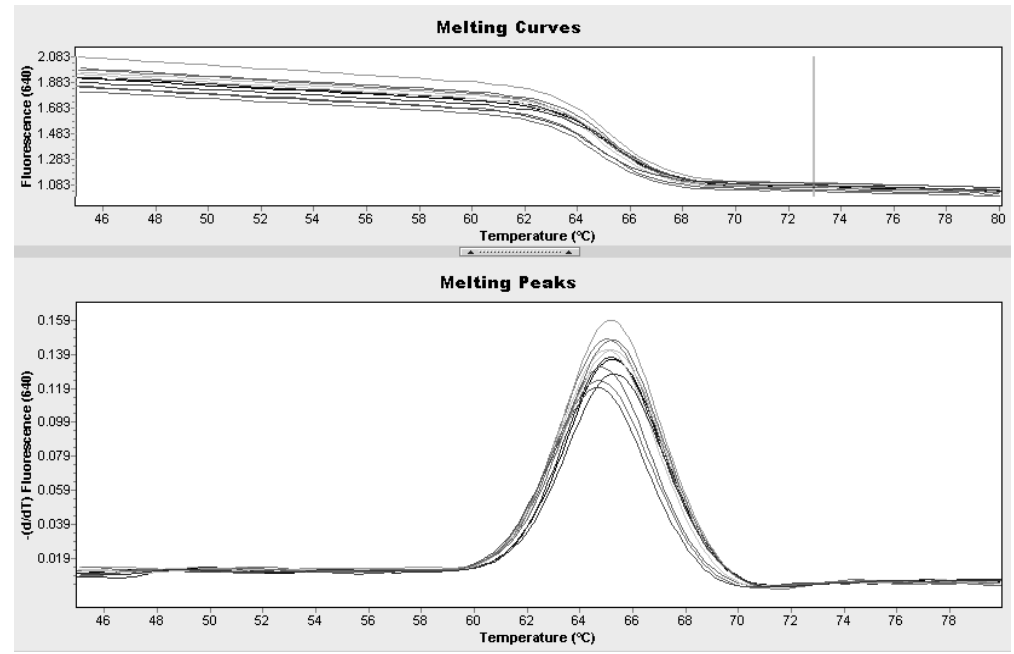

Figure 4. The graphical representation of a normal (wt) genotype (UMCL 2018 laboratory)

One mutated allele was detected in position 1691 of the coagulation factor $\mathrm{V}$ gene (G/A) while analyzing the heterozygotic (het) material, and in the graphic display 2 peaks were obtained, one peak of Tm. about 57.5 (allele with mutation) and the other of Tm 660C (allele without mutation) (Figure 5). The homozygotic mutation (mut), two mutated alleles were visible in position 1691 of the coagulation factor V gene (A/A), graphically visible 
as one peak only - Tm about 57.50C (Figure 6). Heterozygotic and homozygotic mutations are the genotypes responsible for the clinical symptoms of congenital thrombophilia and miscarriages.

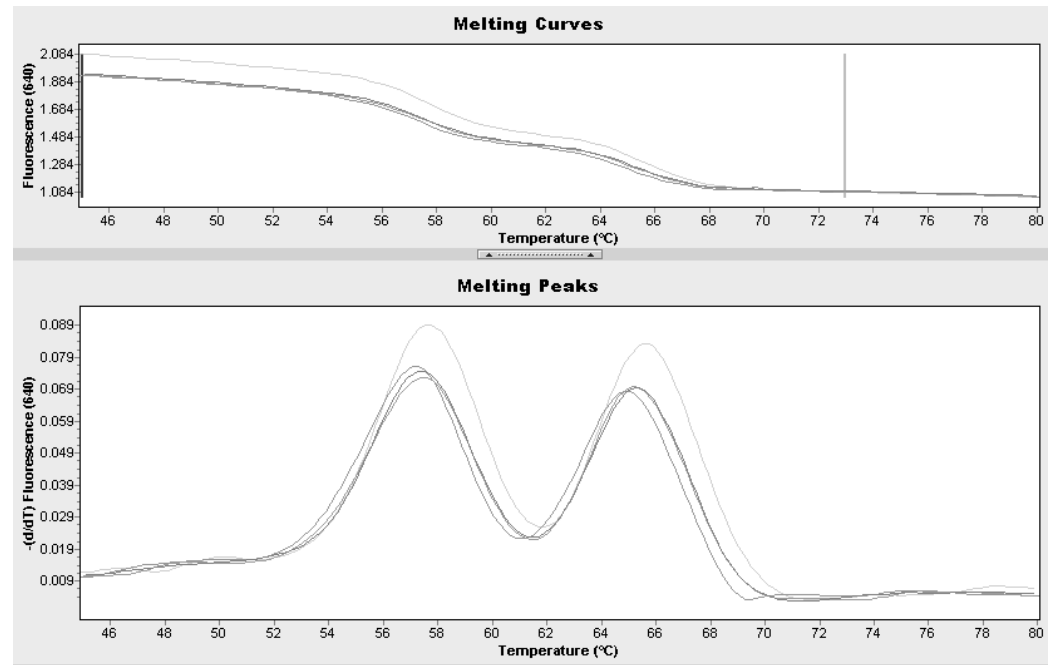

Figure 5. Graphical representation of the heterozygous genotype (het) (UMCL laboratory 2018)

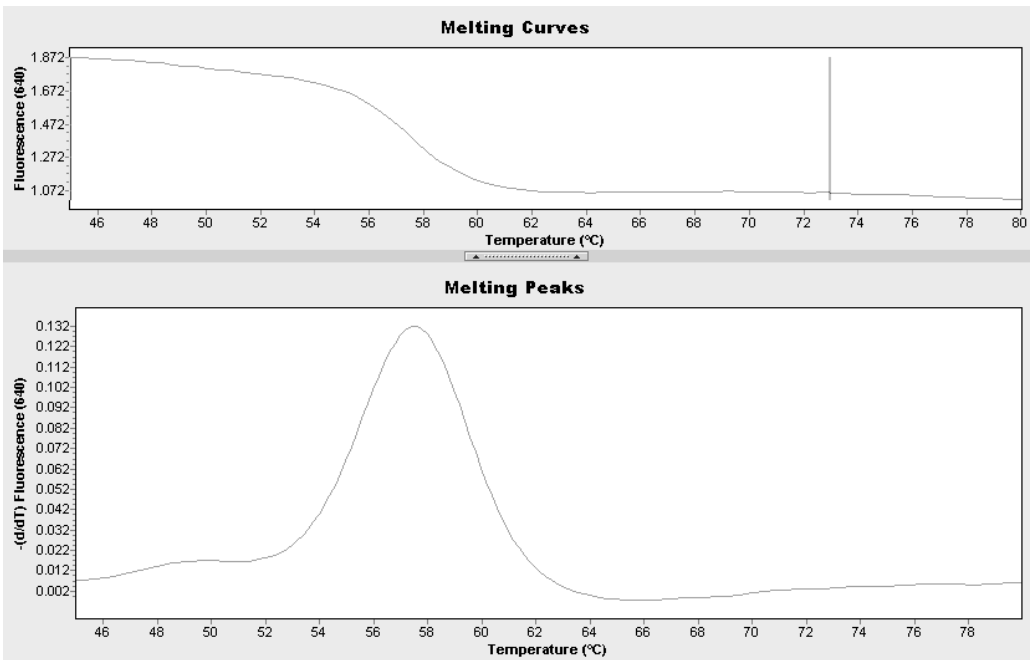

Figure 6. Graphical representation of a homozygous genotype (mut) (UMCL 2018 Laboratory)

\section{Results}

\section{Genotypes prevalence depending on gender}

The patients were divided into two groups: women (1284 cases - 73.5\%) and men (462 cases - 26.5\%). Taking into account all the diagnosed persons both in the male and female group, possible genotypes were determined (Table 1). However, the data analysis for each group showed that the percentage share of heterozygous genotype (het-genotype with mutation) in both examined groups of patients was similar. In the group of women this share was estimated at $99.5 \%$, and in the group of men $93 \%$. Similarly, the homozygous genotype (mut - genotype with a mutation) occurred in the group of women at $0.5 \%$ frequency, and in men at $7 \%$ (Figure 7). 
Table 1. Genotypes displayed according to the patient's gender

\begin{tabular}{|c|c|c|}
\hline \multirow{2}{*}{ Genotype } & Women & Patients \\
\cline { 2 - 3 } & $1089(84.81 \%)$ & $350(75.76 \%)$ \\
\hline $\begin{array}{c}\text { recessive homozygote }(w t) \\
\text { without mutation }\end{array}$ & $1(0.08 \%)$ & $8(1.74 \%)$ \\
\hline $\begin{array}{c}\text { dominant homozygote }(m u t) \\
\text { with a mutation in two alleles }\end{array}$ & $194(15.11 \%)$ & $104(22.5 \%)$ \\
\hline $\begin{array}{c}\text { heterozygote }(\text { het }) \\
\text { with a mutation in one allele }\end{array}$ & & \\
\hline
\end{tabular}

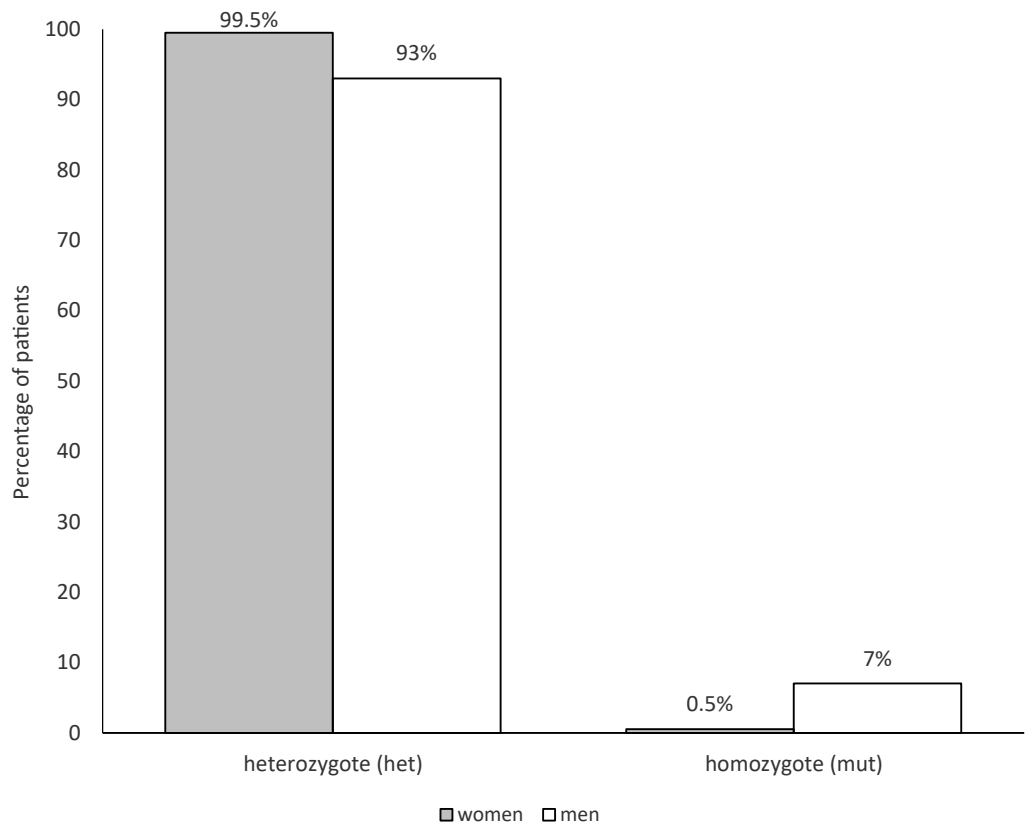

Figure 7. The prevalence of mutation (het, mut) according to gender

\section{Leiden mutation prevalence by gender}

In the analysis of the prevalence of Leiden mutation in the factor $\mathrm{V}$ gene that determines blood clotting statistically significant differences in its occurrence between the groups of women and men $\left(\chi^{2}=4.47, \mathrm{df}=1\right.$, $\mathrm{p}=0.035$ ) were shown. The mutation was diagnosed more frequently in the male group (25\%), and in the female group the gene defect was detected with the frequency of $15 \%$ (Figure 8).

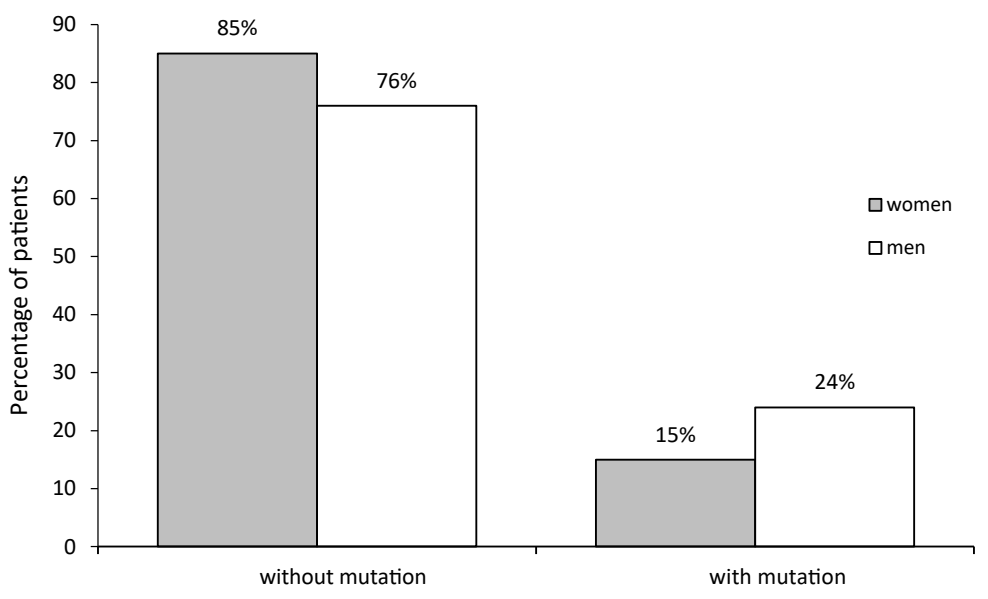

Figure 8. The prevalence of Leiden mutation according to gender 
The prevalence of Leiden mutation depending on the age of patients

In the group of diagnosed women (1284 cases) factor V mutation was the most frequent (31\%) in the age range from 30 to 40 years. The rarest incidence of only $1 \%$ occurred in the 80-90 age group. In the group of men (462 cases), similarly as in the case of women, it was most often (22\%) identified in the age group of 30-40 years, and the rarest incidence (5\%) was found in the age group of 70-80 years (Figure 9).

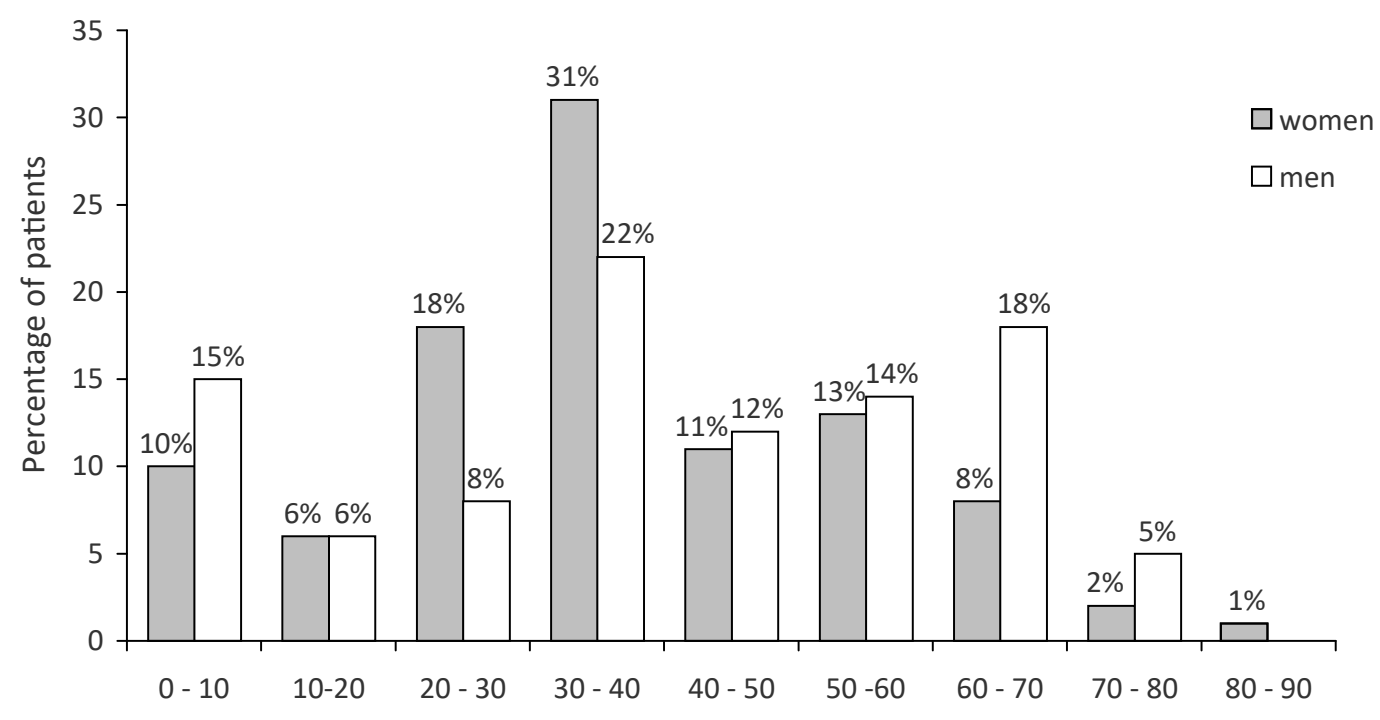

Age groups

Figure 9. The prevalence of Leiden mutation depending on the age of patients

\section{Discussion}

The main indication for genetic testing for congenital thrombophilia are recurrent deep vein symptoms. In patients with unusual location of deep vein thrombosis, molecular diagnostics should be performed. These may include upper limb, visceral and cerebral clots as well as pulmonary embolism, stroke or myocardial infarction, especially at an early age. Molecular studies should be obligatory for women with recurrent miscarriages or stillbirths [13-15]. The Leiden mutation (G1691A) of factor V gene is diagnosed in 20\% of patients who reported clinical symptoms of thrombosis for the first time. Currently, it is the most frequently diagnosed point mutation which determines family thrombophilia [11]. The majority of patients screened for the factor V Leiden mutation are carriers of a single mutation in this gene. Molecular diagnostics is the basis for selection and analysis of medical interventions, such as hospitalization, as having even one version of the mutated gene leads to an increased risk of thromboembolism.

This study focuses on analysis of the genotypes prevalence in patients referred for molecular diagnostics. In the study it was shown that the percentage of heterozygotes and homozygotes in both men and women was similar. It is noteworthy that there were significantly less homozygotic mutations in both groups. It probably results from the way this genetic defect is inherited. The Leiden mutation is inherited in an autosomal dominant manner, which means that inheritance of a mutated allele is sufficient for the disease to occur. Presence of two mutated allele may be lethal. Literature data prove that in people with heterozygous allele set the risk of venous thromboembolism is 4-7 times higher and in homozygotes 50-100 times higher than in people with a correct version of this gene. In the group of patients with a homozygous set of mutated alleles (with V Leiden mutation) $50 \%$ of the patients had an embolism and the probability of ischemic stroke was 5 times higher $[7,11,15,16]$. According to the literature data, $40 \%$ of Leiden heterozygotes had no thrombotic complications until the age of 60 and the risk of recurrence of thrombosis in these cases was low, however, the probability of ischemic stroke increased 7-fold [15-17].

In this study the prevalence of the $\mathrm{V}$ Leiden gene mutation depending on the age of patients was also analyzed. It was shown that the mutation was diagnosed at similar age in both women and men group. The least numerous group referred for G1691A mutation of factor V gene screening were patients aged from 80 to 
90 years $(0.3 \%$ in both groups). The point mutation was most often confirmed in patients of both sexes between 30 and 40 years of age (women 31\%, men 22\%), while it was the rarest in patients over 70 years of age. It is believed that physiological aging is accompanied by many changes in the hemostasis system, which may lead to hematological complications such as hypercoagulability. The Leiden mutation found in these individuals, as an additional unfavorable genetic factor, increases the risk of complications in the form of ischemic strokes, myocardial infarction or thrombosis of an unusual location. In this regard, in Denmark, Great Britain and Italy, population studies on the presence of G1961A mutation of factor V gene were conducted. They included groups of people aged 80 years and more. It was found that the prevalence of this mutation in people over 80 years of age was similar to that of the whole population [18]. In our study, the mutation was detected in about $1 \%$ of the examined women in the age span between 79-90 and in men aged between 70-80, which differs significantly from the literature data.

It is estimated that Leiden mutation occurs even in 15\% of Europeans (Central European countries, Germany, Cyprus) and in about $40-50 \%$ of people with a positive family history of thromboembolism. This mutation is the most frequently detected Caucasian congenital thrombophilia factor (most often in Greece) and ranges from 2 to $7 \%$. A small share of its occurrence is seen in the black race of African origin, Chinese, Japanese and other Asians. In the Polish population this genetic defect occurs in about $8 \%$ of the population. In this group, in about $20 \%$ of the examined persons, clinical symptoms of deep vein thrombosis were present. The subjects were between 30 and 50 years of age, so their mean age was 45 years $[7,11,15,19-22]$. This thesis is confirmed by the results of our own research, where about $18 \%$ of the examined persons were diagnosed with the mutation.

The study compared the frequency of Leiden mutation between a group of women and a group of men. Our own results show significant differences between those groups. The mutation was diagnosed more often in the group of men (25\%), while in women a defect in the gene was detected with a frequency of $15 \%$. Literature proves that women are the ones who contract thrombosis earlier than men. Moreover, literature data indicate that the average age of appearance of thrombosis symptoms in a woman is 34 and 44 years. Men with thrombophilia are more likely to experience recurrent thrombosis. Some scientific papers report that men are more frequently affected by thrombosis than women, but there are also data that suggest that it occurs with the same frequency in both genders. According to other reports, men are more prone to exhibit symptoms after the age of 40 than women $[3,10,15,23]$. Unfortunately, the authors of numerous publications do not specify in which sex, the mutation of gene G1961A (factor V gene) is more frequently found. This probably results from the fact that genetic screening for this mutation is not performed routinely as a form of prophylaxis. It can be assumed that people were referred to such tests only because of symptoms of thrombosis or other hematological problems, which explains the difference between the data obtained in our research and literature.

In the analyzed group of patients undergoing molecular tests for Leiden mutation, by far the largest group were women of so-called reproductive age between 30-40 (42.5\%), which may be related to temporarily increasing risk factors during this period of life, e.g. use of contraceptives, pregnancy or childbirth. It can be assumed (we do not have any data on this subject) that this group could include people referred for congenital thrombophilia screening as a result of complications related to recurrent miscarriages or other obstetric failures. Numerous literature data confirm the influence of congenital thrombophilia on obstetric complications, especially in the first trimester of pregnancy (7-12 weeks) [13, 24, 25]. Pregnancy is a physiological condition of a woman in which blood coagulation and fibrinolysis changes occur. There is also a view that pregnancy itself is a state of hypercoagulation [2, 26]. In 1996 the first case of a woman with thrombophilia, who suffered from thrombosis and its complications, such us recurrent miscarriages, was described $[24,27]$. The Leiden mutation constitutes about $20 \%$ of obstetric complications cases involving, among others, restriction of fetal growth, premature placenta separation, pre-eclampsia or eclampsia, recurrent miscarriages and the occurrence of venous thromboembolic disease (VTE). The occurrence of this disease in pregnant women increases the risk of late fetal loss threefold $[13,28,29,30]$. Numerous observational studies indicate that thrombophilia, including factor $\mathrm{V}$ gene mutation in pregnant women, significantly increases the risk of venous thrombosis, cerebral venous sinus thrombosis and even myocardial infarction [11,31]. Based on clinical trials, it was found that women who have the heterozygous form of the $\mathrm{V}$ Leiden mutation represent about $40 \%$ of cases displaying symptoms of venous thrombosis during pregnancy. In pregnant homozygotes with a positive family history of venous thrombosis in first-degree relatives, the risk of thrombosis complications increases several times. In women with one or two versions of the mutated factor $\mathrm{V}$ gene, the risk of thromboembolism increases as much as 7 times with contraceptives [26, 32, 33].

As a result of successive and continuous scientific studies, the pathogenesis of recurrent miscarriages has been clarified, in particular the existing close relation between them and genetic thrombophilia (including Leiden $\mathrm{V}$ gene mutation). Only a few authors of these publications do not agree that there is an unambiguous 
causal link between congenital thrombophilia and pregnancy complications [27, 34]. There are also theories (which are controversial) about the participation of fetal thrombophilia in obstetric complications, referring to homozygous forms of factor $\mathrm{V}$ Leiden mutation. To confirm this theory, some experts in their work proved the presence of congenital thrombophilia in $8.6 \%$ of aborted embryos $[21,35]$. In reference to their own research, they studied also the group up to the first year of life which accounted for about $1.5 \%$ cases, which may confirm the assumptions mentioned above.

The presence of congenital thrombophilia in children, which results in the development of venous thromboembolic disease (VTE) later in life, is poorly understood due to a small number of studies in this age group. However, in recent years an increase in the incidence of thromboembolism has been observed in children. Some experts explain this by therapeutic measures taken to cure the basic disease (e.g. sepsis, necrotizing intestinal inflammation, cancer), which were previously the cause of neonatal mortality, which could explain the small number of children up to the first year of life screened for the presence of factor $\mathrm{V}$ Leiden mutation. The role of genetic factors in the pathogenesis of childhood thrombosis is being increasingly emphasized. In children and newborns, the best documented and most common cause of congenital thrombophilia is protein $\mathrm{C}$ deficiency, which causes neonatal thrombosis [36-38]. Studies conducted in Denmark show that thromboembolic disorders in children vary from $10 \%$ to $59 \%$. In the group of children examined there as many as $41 \%$ of those with symptoms of thrombosis were also diagnosed with congenital thrombophilia. The available literature data show that G1691A mutation of factor V Leiden is one of the main causes (after protein C and S deficiency) of hereditary venous thromboembolic disease, which was confirmed in about 4.7-13\% of the examined children with thrombosis. These data are based on research that has been conducted twice in the group of 27 children under the age of $18[39,40]$. The factor $V$ Leiden mutation was confirmed in about $15 \%$ of girls and about $18 \%$ of the boys under 18 years of age, which is slightly different from the literature data. Unfortunately, in this age group there are also no data on past venous thromboembolism episodes.

\section{Conclusions}

1. Congenital thrombophilia associated with coexistence of G1691A mutation in Leiden V gene was significantly more frequent in men (25\%) than in women (15\%).

2. All possible genotypes of G1691A mutation occurred in the population of the subjects. The distribution of dominant homozygotes (AA) and heterozygotes (Aa) was similar in women and men.

3. In both women and men, the factor $\mathrm{V}$ Leiden mutation was most frequently detected in the age range from 30 to 40 years. The risk of venous thromboembolism in this age group is highest.

\section{References:}

1. Jastrzębska M. [Laboratory diagnostics in homeostasis]. Warszawa: Oinpharma; 2009 (in Polish).

2. Windyga J. [Coagulation disorders in everyday medical practical practice. $1^{\text {st }}$ edition]. Poznań: Termedia; 2017 (in Polish).

3. Cushmann M, Tsai AW, White RH. Deep vein thrombosis and pulmonary embolism in two cohorts: the longitudinal investigation of thromboembolism etiology. The American Journal of Medicine. 2004; 117(1): 19-25. https://doi.org/10.1016/j.amjmed.2004.01.018

4. Kozdrój B, Noszczyk W. [Venous thromboembolism - procedures in the practice of a general practitioner]. Przewodnik Lekarski. 2004; 4(7): 22-30 (in Polish).

5. Nordström M, Lindblad B, Berggvist D, Kjellström T. A prospective study of the incidence of deep-vein thrombosis within a defined urban population. Journal of Internal Medicine. 1992; 232(2): $155-160$. https://doi.org/10.1111/j.1365-2796.1992.tb00565.x

6. Odnoczko E, Baran B, Windyga J. [To be on first-name terms with homeostasis]. Grudziądz: Wyd. Bio-Ksel; 2016 (in Polish).

7. Wojtasińska E. [Inherited thrombophilia as a risk factor of venous thromboembolism] [dissertation]. Poznań: Poznan University of Medical Sciences; 2014 (in Polish).

8. Gutknecht P, Łuszczyńska-Nitka G, Siebert J. [Venous thromboembolism in the practice of a general practitioner]. Forum Medycyny Rodzinnej. 2007; 1(2): 115-124 (in Polish).

9. Nalewczyńska A, Maździarz A, Krynicki R, Śpiewankiewicz B. [Venous thromboembolism - epidemiology and prophylaxis]. Current Gynecologic Oncology. 2015; 13(3): 191-200 (in Polish).

10. Oger E. Incidence of venous thromboembolism: a community-based study in Western France. EPI-GETBO Study Group. Groupe d'Etude de la Thrombose de Bretagne Occidentale. Thrombosis and Haemostasis. 2000; 83(05): 657-660. 
11. Undass A. [Thrombophilia states]. In: Gajewski P, Augustynowicz-Kopeć E., editors. [Interna Szczeklika: internal diseases handbook]. Kraków: Wydawnictwo Medycyna Praktyczna; 2013. p. 1768-1771 (in Polish).

12. Prandoni P, Vilalta S, Bagatella P, Rossi L, Marchiori A, Piccioli A, et al. The clinical course of deep-vein thrombosis. Prospective long-term follow-up of 528 symptomatic patients. Haematologica. 1997; 82(4): 423-428.

13. Bałajewicz-Nowak M, Pityński K, Milewicz T. [The 1691 G > A (factor V Leiden) and $1328 \mathrm{~T}>\mathrm{C}$ V coagulation factor polymorphisms and recurrent miscarriages]. Ginekologia Polska. 2015; 86, 46-52 (in Polish).

14. Emmerich J, Aiach M, Morange PM, Marder VJ, Aird WC, Bennett JS. Thrombophilia genetics. Haemostasis and thrombosis. Philadelphia: Lippincott Williams \& Wilkins. 2013; 962- 972.

15. Zawilska K. [Hereditary thrombophilia and venous thromboembolism]. Hematologia. 2013; 4(1): 35-42 (in Polish).

16. Tsantes AE, Nikolopoulos G, Bagos PG, Banovas S, Kopterides P, Vaiopoulos G. The effect of the plasminogen activator inhibitor-PAI 14 G/5G polimorphism on the thrombotic risk. Thrombosis Research. 2008; 122(6): 736-742. https://doi.org/10.1016/j.thromres.2007.09.005

17. Middeldorp S. Is thrombophilia testing useful?. Hematology ASH Education Program. 2011; 2011(1): 150-155. https://doi.org/10.1182/asheducation-2011.1.150

18. Ziółkowska S, Ziółkowski W, Mądra-Gackowska K, Żekanowska E, Kędziora-Kornatowska K. [Hemostatic disorders in the elderly]. Geriatria. 2018; 12: 104-109 (in Polish).

19. Bertina RM, Koeleman BP, Koster T. Mutation in blood coagulation factor $\mathrm{V}$ associated with resistance to activated protein C. Nature. 1994; 369: 64-67. https://doi.org/10.1038/369064a0

20. Press RD, Bauer KA, Kujovich JL, HeitJA. Clinical utility of factor V Leiden testing for diagnosis and management of thromboembolic disorders. The Archives of Pathology \& Laboratory Medicine. 2002; 126(11): 1304-1318. https://doi.org/10.1043/0003-9985(2002)126<1304:CUOFVL >2.0.CO;2

21. Rajewski M. [The incidence of polymorphisms of factor V genes (G1691A) and prothrombin (G20210a) and antiphospholipid antibodies in women with pregnancy pathologies] [dissertation]. Poznań: Poznan University of Medical Sciences; 2009 (in Polish).

22. Press DC, Cox M, Clegg JB. World distribution of factor V Leiden. Lancet. 1995; 346: 1133-1134.

23. Heit JA, Kobbervik CE, James AH, Petterson TM, Baile KR, Melton LJ. Trends in the incidence of venous thromboembolism during pregnancy or postpartum: a 30 year population-based study. Annals of Internal Medicine. 2005; 143(10): 697-706. https://doi.org/10.7326/0003-4819-143-10-200511150-00006

24. Many A, Elad R, Yaron Y, Eldor A, Lessing JB, Kupferminc MJ. Third-trimester intrauterine fetal death is associated with inherited thrombophilia. Obstetrics \& Gynecology. 2002; 999(5/1): 684-687.

25. Sasson Z, Mangat I, Grande P, Lorrette I. Left atrial appendage thrombusinatrial flutter with no associated disease. Journal of the American Society Echocardiography. 1996; 9(5): 730-732.

26. Barlik M. [The evaluation of the correlation between polymorphisms of coagulation factor VII gene and tissue plasminogen activator inhibitor and recurrent miscarriages]. [dissertation]. Poznań: Poznan University of Medical Sciences; 2014 (in Polish).

27. Sikkema JM, Franx A, Bruinse HW, Nikkels PG. Placental pathology in early onset pre-eclampsia and intrauterine growth restriction in women with and without thrombophilia. Placenta. 2002; 23(4): 337-342. https://doi.org/10.1053/plac.2001.0785

28. Coriu L, Copaciu E, Tulbure D, Talmaci R, Secara D, Coriu D, et al. Inherited thrombophilia in pregnant women with intrauterine growth restriction. Maedica (Buchar). 2014; 9(4): 351-355.

29. Martinelli I, Taioli E, Cetin I. Mutations in coagulation factors in women with unexplained late fetal loss. The New England Journal of Medicine; 2008; 343(14): 1015-1018. https://doi.org/10.1056/NEJM200010053431405

30. Younis J, Brenner B, Ohel G, Tal J, Lanir N, Ben-Ami M. Activated protein C resistance and factor V Leiden mutation can be associated with first - as well as second - trimester recurrent pregnancy loss. American Journal of Reproductive Immunology. 2000; 43(1): 31-35. https://doi.org/10.1111/j.8755-8920.2000.430106.x

31. Rajewski P, Książkiewicz B. [Cerebral venous and sinus thrombosis]. Udar Mózgu. 2010; 12(1-2): 47-50 (in Polish).

32. Gerhardt A, Scharf RE, Beckmann MW, Struve S, Bender HG, Pillny M. Prothrombin and factor V mutations in women with a history of thrombosis during pregnancy and the puerperium. The New England Journal of Medicine. 2000; 342(6): 374-80. https://doi.org/10.1056/NEJM200002103420602

33. Zotz RB, Gerhardt A, Scharf RE. Inherited thrombophilia and gestational venous thromboembolism. Best Practice Research Clinical Haematology. 2003; 16(2): 243-259.

https://doi.org/10.1016/s1521-6926(03)00022-7 
34. Mousa HA, Alfirević Z. Do placental lesions reflect thrombophilia state in women with adverse pregnancy outcome?. Human Reproduction. 2000; 15(8): 1830-1833.

35. Dekker JW, Lind J, Bloemenkamp KWM, Quint WGV, Kuijpers JC, Dorn LJ, et al. Inherited risk of thrombosis of the fetus and intrauterine fetal death. European Journal of Obstetrics \& Gynecology and Reproductive Biology. 2004; 117(1): 45-48.

36. Bartoszewicz L, Kalicki B, Jung A, Żuber J, Rustecka A. [Venous thromboembolism in children - risk factors, prophylaxis and treatment]. Pediatria i Medycyna Rodzinna. 2010; 6(2): 100-105 (in Polish).

37. Gerotziafas GT. Risk factors for venous thromboembolism in children. International Angiology. 2004; 23(3): 195-205.

38. Nowak-Göttl U, Kurnk K, Krümpel A, Stoll M. Thrombophilia in the young. Thrombosis and Haemostasis. 2008; 28(1-2): 16-20.

39. Chalmers E, Ganesen V, Liesner R. Guideline on the investigation, management and prevention of venous thrombosis in children. British Journal of Haematology. 2011; 154: 196. https://doi.org/10.1111/j.13652141.2010.08543.x

40. Smalisz-Skrzypczyk K, Klukowska K, Pawelec K, Matysiak M. [The analysis of the cause of thromboembolism in children]. Postępy Nauk Medycznych. 2013; 9: 640-645 (in Polish). 